\title{
O LEKCJI EMIGRACYJNEJ POLSZCZYZNY PRZEZ MICHALA CHMIELOWCA SŁAWOMIROWI MROŻKOWI UDZIELONEJ (I KILKU INNYCH SPRAWACH)
}

\author{
Waclaw LEWANDOWSKI (Toruń)
}

Zaczęło się od odpowiedzi Józefa Mackiewicza na ankietę „Wiadomości” dotyczącą twórczości dopiero co zmarłego Witolda Gombrowicza, rozpisaną przez Michała Chmielowca, zastępującego chorego Mieczysława Grydzewskiego na stanowisku redaktora londyńskiego tygodnika ${ }^{1}$. Mackiewicz, który Gombrowicza uważał raczej za sprytnego szarlatana niż artystę, powiedział m.in.:

[...] tajemnica powodzenia Gombrowicza jest, moim zdaniem, dosyć prosta. Gombrowicz nie umiał pisać i nie miał nic do napisania. Zastosował więc chwyt, jakiego używają malarze, którzy nie umieją malować i nie mają nic do namalowania: ukrycie treści, a raczej jej braku, pod niezrozumiałą dla otoczenia formą. Czym mniej treści, tym bardziej niezrozumiała forma. Trzeba się tylko nie obawiać absurdu. Czym większa rozpiętość pomiędzy rozumieniem i utworem, tym większym durniem okazuje się czytelnik, tym większym geniuszem autor utworu. Bo „łatwiznę” potrafi zrozumieć każdy. „rzeczy trudne” natomiast - wyłącznie elita umysłowa. Jest to formuła prosta i tym razem zrozumiała. A któż chce być durniem!

Rzecz oczywista, że nie każdemu taki trik się udaje, lub udać może. Pomijając zakulisowe okoliczności, o których tu mówić nie będę, wymaga [to] swoistego talentu. I talent w tym kierunku należy Gombrowiczowi niewątpliwie przyznać ${ }^{2}$.

${ }^{1}$ O okolicznościach rozpisania ankiety zob. : M. A. Supruniuk, Gombrowicz i emigranci, [wstęp do:] Gombrowicz emigrantów, oprac. tenże, Torun 2006, s. 18-19.

${ }^{2}$ Wiadomości 1969 nr 40 (1227), s. 3 z 5 października; cyt. za: Gombrowicz emigrantów, s. 40. 
O czym myślał, precyzyjnie wyjaśnił Józef Mackiewicz w prywatnym liście do Michała Chmielowca z 25 października 1969 roku.

Pisząc o ,zakulisowych okolicznościach” miałem na myśli co innego. Kiedyś już zresztą pisałem o tym w „Wiadomościach”, wówczas nie wymieniając Gombrowicza: gdy pisarz Ałdanow ${ }^{3}$ zwrócił się do tzw. „Kongresu Obrony Kultury” w Ameryce, aby udzielił jakiejś pomocy przebywającemu po ostatniej wojnie w dosłownej nędzy, jednemu z największych pisarzy, laureatowi nagrody Nobla, [Iwanowi] Buninowi „Kongres Kultury” wyasygnował dolarów 300...! [...] Gdy natomiast kilka lat później pan „Kocio” Jeleński zakrzątał się o pieniądze dla, nieznanego wówczas w świecie, Gombrowicza (który zresztą już otrzymywał subsydia z Free Europe), — otrzymał sporo tysięcy dolarów!

Dokładnej cyfry nie pamiętam. Bodajże sam Gombrowicz był na tyle przyzwoity, że wymienił ją w jednym ze swych „dzienników”. Tak samo jak nie ukrywał, a ogłosił, że brał pieniądze od Free Europe.

Co więc miałem na myśli? Potęgę zakulisowych chodów. Nic więcej. Do jednego z tych potentatów zaliczam Jeleńskiego. Gdyby nie ten „Kocio”, sądzę że Gombrowicz umarłby w Argentynie, znany tylko garstce Polaków.

Nie ma w tym, oczywiście, cienia ,zakulisowego świństwa”. Jest tylko kawałek życia i powodzenia literackiego 4 .

Wyjaśnienie Mackiewicza jest odpowiedzią na list Michała Chmielowca, którego treści nie znamy, jako że jego kopia, jeśli założyć, że została sporządzona, nie zachowała się w redakcyjnym archiwum „Wiadomości”. Pewne jest natomiast, iż to nie intuicja podpowiedziała autorowi Drogi donikad, że jego wzmiankę o działaniach zakulisowych ktoś mógłby zrozumieć jako insynuację — przypisanie autorowi Ferdydurke zabiegów niegodnych, jednym słowem — „świństw”. Wygląda na to, że Chmielowiec przesłał Mackiewiczowi do wglądu list innego korespondenta i swoją odpowiedź, zawierającą wytłumaczenie, dlaczego nie zostanie on ogłoszony na łamach londyńskiego tygodnika. Autorem listu, adresowanego „do Redakcji” pisma był Sławomir Mrożek, od 1968 roku mieszkający w Paryżu. Mrożek nie krył oburzenia, jakie wzbudziła w nim odpowiedź Mackiewicza na ankietę. Skrupulatnie wyliczył wskazane przez autora Kontry przyczyny rozgłosu Gombrowicza, nie kryjąc, że najsilniej zaintrygowała go ta z nich, na którą wskazywało znaczące niedopowiedzenie:

Jednakże trzecia okoliczność, dzięki której Witold Gombrowicz zdobył sobie powodzenie, nie jest już wyłożona przez Józefa Mackiewicza tak jasno, jak dwie poprzednie. Pisze w dalszym ciągu Józef Mackiewicz: „... Rzecz oczywista, że nie każdemu taki trik się udaje, lub udać może. Pomijając zakulisowe okoliczności, o których tu mówić nie będę, wymaga swoistego talentu".

Rozbiór gramatyczny może dopomóc czytelnikowi, ale tylko do pewnego stopnia. Kto, co wymaga „swoistego talentu”? Domyślam się, że „swoistego talentu” wymaga ów „trik” z poprzedniego zdania, ten sam, który „nie każdemu się udaje”.

Pozostaje jednak tajemnicze zdanie: „Pomijając zakulisowe okoliczności, o których tu mówić nie będę".

Nie ulega wattpliwości, że owe „zakulisowe okoliczności” są w jakiś sposób związane z owym „trikiem”. A mianowicie sprzyjały mu, względnie, podobnie jak „trik” i równolegle do niego, prowadziły do tego samego co „trik” efektu. Do powodzenia.

Jakie to były okoliczności?

\footnotetext{
${ }^{3}$ Mark Ałdanow, właściwie Mark Aleksandrowicz Landau (1889-1957), rosyjski pisarz i publicysta emigracyjny, autor powieści historycznych, współinicjator miesięcznika „Nowyj Żurnał” (Nowy Jork).

4 J. Mackiewicz, B. Toporska, Listy do Redaktorów ,Wiadomości”, Londyn 2010, s. 372-373.
} 
Zakulisowe.

Takie, o których Józef Mackiewicz mówić nie będzie.

Dlaczego?

Dlaczego nie będzie mówił, jeżeli je zna?

Dlaczego Józef Mackiewicz coś wie, ale nie powie?

Jest tylko jedno wythumaczenie: te okoliczności są skandaliczne. Nie nadają się do opublikowania.

A więc trzecim sposobem, w jaki Witold Gombrowicz zdobył sobie powodzenie było świństwo. Józef Mackiewicz je zna, ale nie powie. Albo ze względów delikatności wobec nieżyjącego już Witolda Gombrowicza, albo z obrzydzenia do świństw w ogóle.

Nie wiem, jakie świństwo zrobił Witold Gombrowicz.

Natomiast wiem, jakie świństwo napisał Józef Mackiewicz.

W postscriptum Mrożek prosił o opublikowanie listu w „Wiadomościach”. Nie uzgadnianą z Mackiewiczem, o czym świadczy datacja listów, odpowiedź Chmielowca z 14 października 1969 roku warto przytoczyć w całości.

Szanowny Panie!

Proszę wybaczyć te gorzkie słowa krytyki, ale rozumowanie Pana wydaje mi się wadliwe i nie upoważnia Pana do tak ostro, obraźliwie ujętego wniosku.

Życie literackie toczy się nie tylko „na scenie” (w prasie, na publicznych zebraniach itp.), ale i ,za kulisami” (w kawiarniach, w korespondencji prywatnej). Wcale to nie znaczy, że za kulisami muszą się dziać świństwa. Dzieją się i rzeczy szlachetne. Powiedzmy, że nieznany polski poeta daje Panu do przeczytania swoje wiersze. Jest Pan zachwycony. Mówi Pan o tym Giedroyciowi. Giedroyć prosi o wiersze. Daje je do przeczytania Jeleńskiemu. Jeleński jest zachwycony. Spotyka się w kawiarni z francuskim przyjacielempoetą. Namawia go do przełożenia tych genialnych wierszy. Nasz nieznany poeta, nic nawet jeszcze nie ogłosiwszy na scenie, już za kulisami wszedł na drogę do powodzenia. Ani jemu, ani tym, co go ,protegowali”, nie przynosi to żadnej ujmy.

Tak zrozumiałem uwagę Mackiewicza o ,zakulisowych względach”. Gdyby zarzucała Gombrowiczowi lub komukolwiek jakieś „świństwo”, nigdy bym jej nie puścił. Rozumiałem, że Mackiewicz miał tu na myśli entuzjazm i przyjaźń, z jakimi do Gombrowicza odnosiło się kilku ludzi (przede wszystkim Jeleński, co dla mnie jest jego wielką zasługą) mających rozległe znajomości i tzw. chody w francuskich kołach literackich. Mackiewicz może być niezadowolony, że ci ludzi[e] Gombrowiczowi — a nie jemu — torowali drogę, to jego prywatna sprawa czy bolączka. W każdym razie nie napisał nic, co by rzucało brzydki cień na nich czy na Gombrowicza. Na pewno wyraził się niezręcznie, ale nie obraźliwie. Zwracam też uwagę, że pisze: „tu nie będę mówił” (o tych zakulisowych względach), a więc nie twierdzi, jakoby w ogóle nie trzeba czy nie można było o nich mówić.

Całą odpowiedź Mackiewicza uważam za - delikatnie mówiąc - niemądrą i nawet (informacja zakulisowa!) namawiałem go, by ją wycofał. Chętnie zamieszczę jej rzeczową, choćby złośliwą, ale nie obraźliwą krytykę.

Łączę wyrazy poważania

Tonacja tej odpowiedzi zastanawia. Poza wprowadzonymi z rozmysłem elementami komicznymi, jak konfidencjonalne zastrzeżenie, że przekazywana informacja o postawie Mackiewicza jest „zakulisowa”, uderza jakaś pobłażliwość, czy nawet protekcjonalność, z jaką Chmielowiec potraktował Mrożka. Myliłby się ten, kto uznałby, że jest ona pochodną jakiegoś niedoszacowania osiągnięć artystycznych autora Policji. Michał Chmielowiec wysoko cenił jego twórczość, czemu dawał wyraz także na łamach „Wiadomości” na

\footnotetext{
${ }^{5}$ Archiwum Emigracji Biblioteki Uniwersyteckiej UMK w Toruniu, Archiwum „Wiadomości”, Korespondencja redakcyjna, osoby: Mrozowska - Murton, sygn. AE/AW/CCXVI. Tam też kopia odpowiedzi Chmielowca.
} 
długo przed omawianą tu wymianą listów ${ }^{6}$, gdy zaś Józef Wittlin wysuwał do nagrody literackiej tygodnika za rok 1970 Dwa listy i inne opowiadania Sławomira Mrożka, redaktor poparł tę kandydaturę, choć z zastrzeżeniem, że tej książki nie uważa „za szczyt twórczości tego młodego jeszcze pisarza" ${ }^{\text {"7 }}$. Dlaczego zatem pozwolił sobie na thumaczenie jak dziecku w najprostszych słowach i na najprostszych przykładach, co znaczy słowo „zakulisowy" i na czym polega nieoficjalna strona życia literackiego, mimo świadomości, że przemawia do pisarza - „pracownika słowa” i czynnego uczestnika tegoż życia? By odpowiedzieć, trzeba sobie uświadomić, że list Mrożka postawił redaktora w arcytrudnej sytuacji. Związany z Mackiewiczem wieloletnią przyjaźnią, trwającą mimo różnicy poglądów (nie tylko na twórczość Gombrowicza), Chmielowiec nie chciał publikować tekstów krytykujących pisarza, nie mówiąc o tym, że nie miał w zwyczaju ogłaszać listów obrażających kogokolwiek. Mrożkowi należała się jednak odredakcyjna, rzetelna odpowiedź wraz z uzasadnieniem odmowy druku. Układając ją Chmielowiec obrał taktykę najbardziej jak to było możliwe pojednawczą, zmierzającą do obrócenia całej sprawy w dość zabawne nieporozumienie. Uznał przy tym, że najłatwiej i najtaktowniej będzie rzecz przeprowadzić przypominając Mrożkowi (nie wprost!), że wywodzi się on z innej rzeczywistości językowej, czy też innego obszaru polszczyzny, co sprawiło że o językowe nieporozumienie w odczytaniu tekstu Mackiewicza było w tym wypadku łatwo. Każąc Mrożkowi wyobrazić sobie, że z genialnymi wierszami hipotetycznego poety śpieszy do Jerzego Giedroycia (a nie innego emigracyjnego redaktora), Chmielowiec dał do zrozumienia, iż pamięta o spektakularnym geście zerwania z PRL, jakim było ogłoszenie na łamach paryskiej „Kultury” oświadczenia pisarza, protestującego przeciwko udziałowi rządu PRL w zbrojnej agresji na Czechosłowację ${ }^{8}$. Chodziło przecież o to, by uświadomić adresatowi listu pewną różnicę pomiędzy nim a pisarzami „starej” emigracji, nie zaś o to, by go urazić czy zniechęcić. Sens ,językoznawczego" wykładu Chmielowca sprowadzał się do przekonania, że przymiotnik ,zakulisowy” nie jest pejoratywem, więc nie niesie za sobą obligatoryjnie negatywnych znaczeń. Mrożek miał zrozumieć, że padł ofiarą językowego przyzwyczajenia, kalki czy kliszy wywiezionej z kraju. Wprawdzie zerwał z komunistycznym reżimem, nie mógł przecie odmienić faktu, że pisarsko i językowo ukształtował się w Polsce powojennej, której rzeczywistość znacznie odmieniła polszczyznę w stosunku do jej stanu sprzed września 1939 roku. Nie tylko osławiona nowomowa spowodowała te zmiany. Duże znaczenie miały zwyczaje językowe, które z języka władzy i propagandy stopniowo przenosiły się w obszary szersze, stając się zwyczajem społecznym. Właśnie z języka propagandy wziął się zwyczaj postrzegania przymiotnika "zakulisowy” jako pejoratywu, szczęśliwie w dzisiejszej polszczyźnie już nieobecny. W latach PRL „zakulisowy” kojarzył się z „zakulisowymi knowaniami, intrygami” wrogów ustroju przeciwko władzy. Z czasem w powszechnej krajowej świadomości językowej wszystko co „zakulisowe” zaczęło kojarzyć się negatywnie, zawsze oznaczając jakieś działania wrogie, nieprawe, nieuczciwe i ciemne. Chmielowiec liczył, iż uświadomi Mrożkowi, że „stara” emigracja, jak Mackiewicz, używa polszczyzny międzywojennej, bez powojennych przekształceń, toteż nikt ze „starych” emigrantów nie dopatrzyłby się w mówieniu o „zakulisowych oko-

${ }^{6}$ Zob. np.: [M. Chmielowiec] Następca, W oczach Zachodu, Wiadomości 1965 nr 45 (1023), s. 6 z 7 listopada. Tam entuzjastyczne omówienie inscenizacji sztuk Policji i Na pelnym morzu w Royal Lyceum Theatre w Edynburgu oraz „zasłużonych pochwał”, jakie z tej okazji Mrożek zebrał w prasie szkockiej i angielskiej.

7 Od Herberta do Herberta. Nagroda „Wiadomości” 1958-1990, oprac. S. Kossowska, Londyn 1993, s. 179.

${ }^{8}$ Zob.: S. Mrożek, Oświadczenie, Kultura 1968 nr 253, s. 210. Zeszyt specjalny poświęcony wydarzeniom w Czechosłowacji. 
licznościach" żadnej insynuacji ani obraźliwej sugestii, a tylko on sam, Mrożek, wiedziony krajowym nawykiem językowym odczytał błędnie. Nie wiadomo, czy taki wywód Mrożka przekonał, wiadomo natomiast, że decyzję niepublikowania jego listu w „Wiadomościach” za słuszną uznał Józef Mackiewicz. W roku 1970, gdy wypominał Chmielowcowi niepotrzebne skreślenia w podawanych do druku tekstach, przypomniał:

Że ktoś napisał o mnie (Mrożek): ,świństwo”, słusznie że Pan skreślił. Natomiast, że ktoś napisał: „wykazuje aberrację umysłową” — niesłusznie Pan skreślił. Jest to napaść, ale bez rynsztokowego wyzwiska, które nie są dopuszczalne w szanującym się czasopiśmie ${ }^{9}$.

Nie zmienił natomiast Mackiewicz swych sądów o twórczości i postawie Gombrowicza, ba, jeszcze się w nich utwierdził po opublikowaniu przez Jarosława Iwaszkiewicza listów autora Kosmosu w warszawskiej „Twórczości”10. Publikacja ta wywołała na emigracji spore poruszenie. Niektórzy spośród niedawnych admiratorów Witolda Gombrowicza zrewidowali swą dotychczasową opinię. Mówiono tu i ówdzie o pisarzu jako zdrajcy emigracji, kimś, kto walcząc o sławę pisarza-antykomunisty, jednocześnie zabiega o wsparcie komunistycznych władz. Sam Mackiewicz, nie bez utrudnień i przeszkód ze strony Chmielowca ${ }^{11}$, wypowiedział się w formie poświęconej Gombrowiczowi dygresji w artykule o twórczości Sergiusza Piaseckiego.

Niedawna, zawstydzająca jednomyślność ujawniona w ocenie osoby i twórczości Witolda Gombrowicza na łamach „Wiadomości”, zaprezentowała zarazem kolekcję słowną, którą złośliwi mogliby nazwać „pustosłowiem”. Uznano nawet za „niedopuszczalne" (!) podważanie osobistej wielkości Gombrowicza. [...] Nie potrafię się jednak pozbyć przypuszczenia że gdyby znane były już wówczas listy Gombrowicza do Jarosława Iwaszkiewicza (ogłoszone dopiero w grudniowej „Twórczości” warszawskiej), pewna część apologetów mogłaby odpaść. Choć pozornie na ocenę twórczości literackiej nie powinny by wpływać zabiegi o pieniądze u komunistycznego okupanta ${ }^{12}$.

Chmielowiec, który trwał w przekonaniu, że listy Gombrowicza zostały przez Iwaszkiewicza zmanipulowane, opatrzył wzmiankę o ich publikacji „zapytaniem redakcyjnym” — „Czy wszystkie? Czy w tendencyjnym wyborze?”. Mackiewicz wątpliwości redaktora nie podzielał. Pisał:

W listach [do Iwaszkiewicza] od r. 1946 do 1968 [Gombrowicz] płaszczy się zabiegając o materialną podporę komunistycznego okupanta. Zupełnie jednoznacznie. Co by mogło zmienić, gdyby były „wszystkie”, czy nie było „tendencyjnego wyboru”? Że mogły być takie, w których pisze: ,proszę mnie nie pomagać... nie chcę żadnej pomocy”...? To nielogiczne. $Z$ sensu wynika, że takich być nie mogło ${ }^{13}$.

- W tej sprawie miał, oczywiście, rację. Iwaszkiewicz żadnej manipulacji się nie dopuścił. Obrony dobrego imienia Gombrowicza, nie sprowadzającej się do negowania autentyczności i kompletności ogłoszonych w „Twórczości” listów, podjął się Konstan-

9 J. Mackiewicz, B. Toporska, Listy, s. 404 (list z 15 kwietnia 1970.

${ }^{10}$ Listy W. Gombrowicza do J. Iwaszkiewicza, Twórczość 1969, nr 12, s. 8-29; dopełnienie: Twórczość 1970, nr 7-8, s. 128-131.

${ }^{11}$ Listy J. Mackiewicza do M. Chmielowca z 8 i 15 kwietnia 1970 pokazują, jak zażarte boje musiał pisarz toczyć z redaktorem o niemal każde słowo poświęcone Gombrowiczowi. Redaktorskie interwencje Chmielowca sprowadzały się, oczywiście, do łagodzenia tonu wypowiedzi, zob.: J. Mackiewicz, B. Toporska, Listy, s. 401-405.

12 J. Mackiewicz, Sergiusz Piasecki i jego Niedźwiedzica, Wiadomości 1970 nr 20 (1259), s. 1.

${ }^{13}$ List z 8 kwietnia 1970; zob. J. Mackiewicz, B. Toporska, Listy, s. 402. 
ty Jeleński ${ }^{14}$, który notabene podanie tych listów do druku uważał za popełnione przez Iwaszkiewicza świństwo.

\section{ON THE POLISH LESSON DURING EMIGRATION GRANTED TO SLAWOMIR MROŻEK BY MICHAŁ CHMIELOWIEC (AND SOME OTHER MATTERS)}

The article deals with the manqué publishing of Sławomir Mrożek's letter in the London magazine Wiadomości. Mrożek was reacting to a critique on W. Gombrowicz written by J. Mackiewicz. Michał Chmielowiec refused to publish the letter, justifying it with a language misunderstanding caused by the differences in emigration and native Polish.

Keywords: Sławomir Mrożek; Wiadomości; Witold Gombrowicz; Józef Mackiewicz; Polish during emigration.

${ }^{14}$ Zob.: K. A. Jeleński, Czy: , ,inny” Gombrowicz?, Kultura 1970 nr 5 (272), s. 144-149. 